IRSH 62 (2017), pp. 27I-278 doi:I0.10I7/S0020859017000I 53

(C) 2017 Internationaal Instituut voor Sociale Geschiedenis

\title{
Ghostbusting or Real Pluralism? A Brief Response to Peter Ackers
}

\author{
MARCEL VAN DER LINDEN \\ International Institute of Social History, Amsterdam \\ PO Box 2 I69, I000 CD Amsterdam, The Netherlands
}

E-mail: mvl@iisg.nl

\begin{abstract}
All people who work with their hands are partly invisible, and the more important the work they do, the less visible they are. Still, a white skin is always very conspicuous. In northern Europe, when you see a labourer ploughing a field, you probably give him a second glance. In a hot country, anywhere south of Gibraltar or east of Suez, the chances are that you don't even see him. I have noticed this again and again. ${ }^{\mathrm{I}}$
\end{abstract}

Since the start of the new millennium, Global Labour History (GLH) has attracted a growing group of adherents on different continents in South and North alike. Especially young scholars derive inspiration from the broad perspective, the effort to perceive the connections between trends everywhere in the world over the centuries in work, workers, and labour relations, incorporating slaves, indentured labourers and sharecroppers, as well as housewives and domestic servants. Strategically-minded trade unionists are taking an interest in the new field of research as well. Reiner Hoffmann, the President of the German trade-union confederation (DGB), recently described GLH as being immensely important for understanding the challenges that the present labour movement faces. ${ }^{2}$

Dissenting reactions to GLH's popularity were to be expected. The reactions come from two angles. Some believe that GLH marks a rift with Marxism, expressing a populist desire "to recruit virtually everyone into a broad anticapitalist movement". ${ }^{3}$ Others maintain that GLH in fact reflects far too many Marxist influences and should be purged of them. Peter Ackers pertains to the second group. He is, to my knowledge, the first to undertake an explicit antiMarxist critique, for which I am grateful. When Ackers was preparing his article against me, I willingly helped him gather materials. It is good that he has put his ideas in writing, as advocates and opponents need to engage in debate. Unfortunately, his contribution also smacks of the Cold War and of nationalism.

I. George Orwell, "Marrakech" (1939), in Sonia Orwell and Ian Angus (eds), The Collected Essays, Journalism and Letters of George Orwell (London, 1968), vol. I, pp. 387-393, 390.

2. At a meeting of the DGB Discussion Circle on Social and Economic History at the DGB head office in Berlin, Is September 2016.

3. Tom Brass, "Who These Days is Not a Subaltern? The Populist Drift of Global Labor History", Science and Society, 8 I: I (January 2017), pp. I0-34, 3 I. 
If I understand Ackers correctly, his arguments are generally as follows:

- In the I960s, I970s and I980s, labour history came to be dominated increasingly by Marxists (state socialists), while the liberal-pluralist influence of Asa Briggs, Hugh Clegg, Henry Pelling, and others dwindled. The consequence was a regression to abstract idealism, and the lived experience of people was very often neglected.

- The end of Communism in 1989-1990 provided an opportunity to innovate labour history.

To this end, it was and remains necessary "to scrape the [Marxist] ideology and teleology from the overall picture". The history of socialist ideas needs to be disentangled from the history of the working classes, as socialist ideas reflect "a predominantly middle-class experience in most countries. Intellectuals may think in terms of 'the global and the national', while ordinary people are more attached to 'the local and the particular"”.

- The rising popularity of GLH might ruin this opportunity for innovation. The version I advocate is especially dangerous, as it is based on Marxist and therefore on state-socialist principles and thus threatens pluralism.

Before I elaborate on Ackers's arguments, I wish to make very clear that GLH is primarily a scholarly rather than a political project and, as such, is conducted by scholars with divergent views, methodologies, and theoretical perspectives. Any political challenge of GLH is therefore likely to be largely ineffective. Scholars practising GLH are driven by the awareness that the richly variegated traditional labour history did not sufficiently consider transnational and global perspectives. In this respect, GLH is but one of the many "global historiographies" presently gaining currency and helping us relate to the global turn in historiography in general. The question as to whether I (or other Global Labour Historians) are too "Marxist" or not "Marxist" enough therefore has little bearing on the discipline as a whole.

\section{Marxism}

In labour history in the I960s-1980s (at any rate in the first half), Marxist influences increased significantly, not only in Britain but in many other countries as well. Many theories that the new Marxists elaborated tended to be exceptionally diagrammatic and imbued with dogmatism, as Ackers has correctly noted. This situation, however, does not justify overlooking the historically unique revival of labour history that resulted from the rising popularity of Marxism, as well as the many wonderful empirical studies that remain very important to this day. Among them are excellent works, such as Gareth Stedman Jones's Outcast London (I97I), Michelle Perrot's 
Les ouvriers en grève (1974), Luisa Passerini's Torino operaio e fascista (1984), David Montgomery's Fall of the House of Labor (1987), and many others. ${ }^{4}$ During this period, the non-Marxists continued to produce fine contributions, of which Patrick Fridenson's Histoire des usines Renault (1972) and Klaus Tenfelde's Sozialgeschichte der Bergarbeiterschaft (I 977) come to mind, as do the poverty studies by e.g. Olwen Hufton and Gertrude Himmelfarb.' Ackers therefore presents a caricature, when he argues that "intellectuals lost interest in or despaired of the prosaic reformism of the British working classes, in favour of more glamorous, remote and brutal figures such as Mao, Castro and Ho Chi Minh".

Ackers appears to have a Manichean world view. The "good guys" are the liberal pluralists following the tradition of Isaiah Berlin, the "bad guys" the Marxists/state socialists. ${ }^{6}$ He seems to believe that all Marxists advocate statesocialism. Such a simplification attests to ignorance. For example, although I subscribe to a heterodox-Marxist tradition, I do not consider myself to be a state socialist. To address the first part, I regard Karl Marx as one of the greatest thinkers from the past two centuries, who revealed several essential aspects of capitalist dynamics. Many of his insights are, in my view, still current, such as the ongoing commodification of social, cultural, and economic relations, the revolutionary and destructive consequences of the perpetual competition between capitals, and so on. I also believe, however, that Marx's oeuvre comprises substantial inconsistencies and blind spots that necessitate a creative revision and additional elaboration of his perspective. A volume I recently co-edited is titled Beyond Marx with good reason. ${ }^{7}$ Second, believing that all Marxists are state socialists is misguided. Some have a long-standing tradition of rejecting state-socialism, including those known as the council communists

4. Gareth Stedman Jones, Outcast London. A Study in the Relationship between Classes in Victorian Society (Oxford, I97I); Michelle Perrot, Les ouvriers en grève, I871-1890. 2 vols (Paris, 1974); Luisa Passerini, Torino operaio e fascista. Una storia orale (Rome, 1984); David Montgomery, The Fall of the House of Labor. The Workplace, the State, and American Labor Activism, I865-1925 (Cambridge, 1987).

5. Patrick Fridenson, Histoire des usines Renault. Naissance de la grande entreprise (I893-1939) (Paris, 1972); Olwen Hufton, The Poor of Eighteenth-century France 1750-1789 (Oxford, 1974); Klaus Tenfelde, Sozialgeschichte der Bergarbeiterschaft an der Rubr im 19. Jabrbundert (BonnBad Godesberg, 1977); Gertrude Himmelfarb, The Idea of Poverty. England in the Early Industrial Age (New York, 1984).

6. Ackers interprets "state-socialism" very freely, when he asserts: "Our post-war National Health Service and Nationalized industries were shaped by a distinctive local brand of state-socialism." Admittedly, Aneurin Bevan's statement that "no society can legitimately call itself civilised if a sick person is denied medical aid because of lack of means" (In Place of Fear (London, 1952), p. I00) might well have been made by a Marxist. But could it not just as easily come from a socially empathetic Liberal?

7. Marcel van der Linden and Karl Heinz Roth, Beyond Marx. Theorising the Global Labour Relations of the Twenty-first Century (Leiden [etc.], 20I3; 2nd. ed. Chicago 2014). See also Gerald Hubmann and Marcel van der Linden (eds), Marx's Capital: An Unfinishable Project? (Leiden [etc.], forthcoming). 
(Anton Pannekoek, Paul Mattick, Otto Rühle et al.), libertarian Marxists, such as Daniel Guérin, and revolutionary humanists, such as Raya Dunayevskaya and C.L.R. James. These schools have disclosed essential homologies between the Soviet Union and industrial capitalism, giving rise to important ideas for the radical-democratic and egalitarian restructuring of our society. They emphasize autonomous organization from below. I appreciate their views, without agreeing with them in all respects. ${ }^{8}$

Ackers finds all this too complicated and therefore does not know how to respond to the Marxist critics of the Soviet Union and the Chinese People's Republic. Ackers quotes my assertion that these societies were "elements of capitalist civilization, broadly speaking". He then concludes that I "simply dodge the central intellectual problem of why post-capitalist socialism becomes totalitarian". This argument presents problems for two reasons. First, Ackers leaves essential questions unanswered. Were Russia before I9I7 and China before 1949 indeed already capitalist? And is "socialism" truly the best designation for the post-revolutionary societies in Russia and China? Second, Ackers fails to quote my subsequent sentence: "They were, in my view, not 'capitalist', but their rise and decline can only be understood in a world capitalist context." 9 In combination, these two statements provide a crucial nuance: it is precisely the tension between capitalism and non-capitalism that in my view defined the historical trajectory of development dictatorships, such as the USSR. Like Hillel Ticktin and others, I see the USSR as a distinctive social formation without endogenous dynamics, rendering its stagnation and downfall inevitable. This society had nothing to do with socialism. I have explained that in several publications, but Ackers does not address this point. ${ }^{10}$ Doing so would have undermined his line of argument.

\section{Pluralism}

Because of his Manichean world view, Ackers fails to understand that heterodox Marxists may principally favour a pluralist approach. I have repeated my support for a basic pluralist stance on many occasions, arguing that GLH is

8. Marcel van der Linden, "Socialisme ou Barbarie: A French Revolutionary Group, I949-1965", Left History, 5:I (1998), pp. 7-37; ibid., "On Council Communism”, Historical Materialism, I 2:4 (2004), pp. 27-50.

9. Marcel van der Linden, "The Promise and Challenges of Global Labor History", International Labor and Working-Class History, 82 (Fall 201 2), pp. 57-76, 74 note.

Io. Marcel van der Linden, Western Marxism and the Soviet Union. A Survey of Critical Theories and Debates since 1917 (Leiden [etc.], 2007; 2nd ed. Chicago, 2009); ibid., (ed.), Was war die Sowjetunion? Kritische Beiträge zum real existierenden Sozialismus (Vienna, 2007). I envisaged the end of the Soviet Union in Marcel van der Linden, "Inleiding”, in Joost Kircz, Marcel van der Linden and Fritjof Tichelman (eds), Het Sovjetraadsel. Poging tot begrip van de Oosteuropese maatschappij (Antwerp, 1983), pp. 7-I5, I2-I3. This perspective is substantiated at length in Frank Füredi, The Soviet Union Demystified: A Materialist Analysis (London, 1986), and in Hillel Ticktin, Origins of the Crisis in the USSR: Essays on the Political Economy of a Disintegrating System (New York, 1992). 
"a field of attention" and "not a theory to which everyone must adhere". Ackers does not believe that I am sincere about this: "This might be true for other, looser interpretations of GLH", but not for my approach. Ackers appears unable to accept that a Marxist might be willing to engage in serious dialogue with non-Marxists. But the entire GLH project is a concatenation of such dialogues. The foundational text of GLH, the Prolegomena from I999, is in fact the result of collaboration between a non-Marxist (Jan Lucassen) and a Marxist (me). ${ }^{\text {II }}$ At the International Institute of Social History I have been working closely with non-Marxists - consistently in the majority at the Institute - for many years. This teamwork is not a tactical manoeuvre. Non-Marxists tend to highlight different aspects from Marxists, and together we manage to convey a more complete impression of historical reality.

\section{Class}

Ackers believes that Marxist-dominated labour history has imposed structures on the reality lived by "ordinary people" that fail to do justice to their experiences and attitudes. These distortions are to be filtered out to reveal the "true" life and work of the working classes. I agree with part of this position. ${ }^{12}$ I have long advocated a clear distinction between intellectual theories and the ideology of workers. In 1982, for example, I noted (please excuse the dated terminology):

Remarkably, great masses in Marxist theory capture only what is not typically Marxist: for example the presence of fundamental class antagonisms, and of exploitation, that workers have no say in the surplus product they produce, and that the working class can be liberated only through their own efforts. All these "programme points" were formulated by worker-communists prior to Marx and have historically been the outcome of an independent learning process that did not involve intellectuals. Especially the aspects that are typically Marxist (the labour theory of value, the theory of ground rent, the tendential decline of the rate of profit, etc.) have never been processed by the masses. ${ }^{13}$

In advocating "real” experiences, Ackers appears to support E.P. Thompson, who is known to have believed that "[c]lass happens when some men, as a

I I. Marcel van der Linden and Jan Lucassen, Prolegomena for a Global Labour History (Amsterdam, 1999), available at: http://socialhistory.org/sites/default/files/docs/publications/ prolegomena.pdf; last accessed s April 2017.

12. Ackers kindly acknowledges this and refers to some chapters in my book Workers of the World. Essays toward a Global Labor History (Leiden [etc.], 2008). For more elaborate considerations, see also my "Introduction" and "Conclusion" in Jan Kok (ed.), Rebellious Families. Household Strategies and Collective Action in the Nineteenth and Twentieth Centuries (New York [etc.], 2002), pp. I-23 and 230-242.

I 3. Marcel van der Linden, "Over de grenzen van het wetenschappelijk socialisme" [On the Limits of Scientific Socialism], in Marcel van der Linden and Ronald Commers, Marx en het wetenschappelijk socialisme (Antwerp [etc.], 1982), pp. 7-53, 50. 
result of common experiences (inherited or shared), feel and articulate the identity of their interests as between themselves, and as against other men whose interests are different from (and usually opposed to) theirs". ${ }^{14}$ According to this view, it is not the identity of interests as such that makes a class but the feeling and articulation of this identity. In this view, Thompson implicitly took issue with Stalinism - with which he had identified a few years earlier - because it deduced class consciousness from class interests. ${ }^{\text {Is }}$ In his fairly one-sided emphasis on concrete, lived experiences, Thompson did not sufficiently consider social and economic structures in class formation.

Ackers also appears more interested in the experiences of the working class than in the social interrelations within which these experiences take place. I believe, however, that we should integrate both aspects in our narratives and analyses. I do not mean to suggest that experiences are "subjective" and structures "objective". Workers, like other people, are structurally-formed agents who enact and/or transform structures. The structures within which they operate may seem abstract, but: "Abstraction becomes only a moment in the analysis: a necessary strategic move in any complex historical argument. We can introduce structures without ceasing to be ontological humanists, and can recognize the efficacy of 'experience' without ruling out a structural argument." "Such an integral approach reveals that capitalism is progressively globalizing, that wage dependents keep increasing as a consequence (that a global working class is growing in an abstract sense), that most "ordinary people" think in terms of "the local and the particular", that the nation is "alive and kicking", and that internationalism is "a largely peripheral working class experience". Ackers is creating a problem that is not there.

Working classes have always been heterogeneous in many respects, both within and between countries. Because the total number of workers continues to increase all over the world and has by now reached about three billion, this heterogeneity is likely to have increased still further. Differences in affluence are vast. A woman working in SubSaharan Africa is likely to make one fiftieth of what her counterpart in Germany is paid. Ackers's "'real worlds of labour', as experienced by ordinary people" differ significantly and can obviously not be captured in a structural category such as "the world working class". This is precisely why I previously designated that world working class

I4. E.P. Thomson, The Making of the English Working Class (London, 1963), p. 9.

I s. Marcel van der Linden, "Il farsi del The Making", Contemporanea. Rivista di storia dell' 800 del'900, 9:4 (October 2008), pp. 748-754.

I6. William H. Sewell, Jr., "How Classes are Made: Critical Reflections on E.P. Thompson's Theory of Working-class Formation", in: Harvey J. Kaye and Keith McClelland (eds), E.P. Thompson: Critical Perspectives (Cambridge, 1990), pp. 50-77, 66. 
as a "multitude". ${ }^{17}$ The ideas elaborated by Max Weber and other nonMarxist sociologists about social exclusion, credentialism, differential social statuses, etc. may be very useful in analysing such "real worlds of labour". There is no irreconcilable contrast in this respect, as Ackers seems to believe. ${ }^{18}$

\section{Similarities}

Although Ackers suggests that he is staging a frontal attack on - my interpretation of - GLH, his arguments are not so adversarial after all. According to Ackers, "elements" of his own approach "are quite compatible with looser reading of the new GLH". After all, "no Labour Historian can refuse to cross national borders", as the world is "becoming more global", and often "national membranes are more permeable". In Britain, "the next generation will be more interested in the cross-national connections that GLH champions". This might be a promising start for a fruitful dialogue: the next generation already resounds, and even Ackers "admits" that he recently practised transnational history! Incidentally, he refutes his own appeal for "a strong defence" of methodological nationalism here.

Ackers argues that he does not object to cross-border studies, merely to "globalization as a normative agenda". What he means here is unclear. I have never actually met Global Labour Historians (Marxists or nonMarxists) who regarded the capitalist globalization, as it has taken place in recent decades, as a "normative agenda". Many in fact object to the present globalization, not for nationalist reasons (as Ackers seems to do), but because they support a different, humane globalization.

\section{A final word}

Ackers aims to oppose my approach to GLH on the Black Swan principle by demonstrating that my "new universal model" (not truly intended as a model at all!) does not work for Britain and therefore not for the rest of the world either. Instead, however, he makes largely unsubstantiated assertions. Marxism is not the same as state-socialism; intellectual pluralism is not in

17. Marcel van der Linden, "Labour History as the History of Multitudes", Labour/Le Travail, 52 (2003), pp. 235-243; idem, "Labour History Beyond Borders", in Joan Allen, Alan Campbell and John McIlroy (eds), Histories of Labour. National and International Perspectives (London, 2010), pp. 353-383, 367 .

18. Keep in mind that Georg Lukács, possibly the most influential Marxist philosopher of the twentieth century, was not only a friend of Max Weber but also incorporated essential elements of Weber's ideas in his theories. See Georg Lukács, History and Class Consciousness. Studies in Marxist Dialectics. Trans. Rodney Livingstone (London, I971), esp. pp. $95-96$ and 31 8; Andrew Arato and Paul Breines, The Young Lukács and the Origins of Western Marxism (London, 1979), esp. pp. II $3-160$. 
danger; local and particular experiences are not at odds with the idea of a world working class. Let me conclude with a quotation from George Orwell, whom we apparently both admire: "To write in plain, vigorous language one has to think fearlessly, and if one thinks fearlessly one cannot be politically orthodox." ${ }^{9}$ This holds true, I suppose, for "Marxists" and "liberal pluralists" alike.

19. George Orwell, "The Prevention of Literature" (1946), in Collected Essays, vol. 4, pp. 59-72, 66. 